\title{
“What Happen Next?” Strategy to Improve Students Skill on Writing Narrative Text
}

\author{
Sri Wahyuni \\ wahyunialid@yahoo.com \\ SMAN 02 Selong
}

\begin{abstract}
Most of the EFL learners, especially at senior high schools, frequently consider that writing is the most difficult skill compared to the three other language skills. This difficulty was also faced by the second year students of Madrasah Aliyah Muhammadiyah Malang. The results of their writing performance at the preliminary research indicated that on average they achieved low grades in writing narrative texts. Moreover, the students in this school were not motivated in writing. For this case, the writer applied a strategy "what happen next?" which can improve the skill in writing narrative texts. The strategy was implemented in action research through four steps: planning, implementing, observing, and reflecting. The action research was conducted in two cycles and involves 24 students. The results of the findings showed the improvement of the students' skill in writing narrative texts and also the improvement of the students' involvement in the writing activities during the teaching and learning process.
\end{abstract}

Keywords: Narrative Text, Writing Skill, “What Happen Next?” A Story-Retelling Strategy

\section{Introduction}

Listening, speaking, reading and writing are the language skills that EFL learners require in order to be able to use the language effectively. The four skills must support each other. Take an example, when the learners concern to listening, they will write what they are listening, and then they must understand their writing through reading. Furthermore, when a teacher asks question about the content and the message of the text being listened and the students answer the question, which means speaking is performed. Thus, integrating the four skills in teaching language should be done by the English teacher in classroom. In Indonesia, English is taught as a foreign language and its aim is to enable students to master the four language skills: listening, speaking, reading, and writing (Depdiknas, 2006). 
However, from those four skills writing is considered as the most difficult skill to be taught. This is because this skill requires ability to concern more about all elements of the languages. Expressing the idea, combining the sentences into a good paragraph, combining one sentence to the other sentences, selecting the suitable vocabularies, constructing the sentences by using correct structure and sequencing every idea to make the text coherent are the activities in writing process. These activities are usually regarded as difficult processes. This idea is supported by Richard and Renandya (2002) who reveal that there is no doubt that writing is the most difficult skill for second language learners to master. The difficulty lies not only in generating ideas but also in translating these ideas into readable text. Cahyono and Widiati (2011) reveal that writing is often believed to be the most complex one compared to the other three skills. Moreover Alsamadani, (2010) explains that this skill is also assumed as a complex, challenging, and difficult process because it includes discovering a thesis, developing support for it, organizing, revising, and finally editing it to ensure an effective, error-free piece of writing. Therefore, based on the assumption that writing is the most difficult skill, it should be taught as attractive as possible. A teacher should find the effective and interesting strategy or method in teaching this skill in order the students get a pleasure in producing a written text.

The curriculum in Indonesian education system on Kurikulum Tingkat Satuan Pendidikan (School-based Curriculum), English subject consists of the basic competences of each language skill which must be achieved by the learners or students in each level of education. One of the competences is writing some kinds of texts. The basic competences of writing are mentioned in the curriculum rely on the competences to write text or genre based. For example, the competence standard of writing in the curriculum for SMA grade XI states: "Mengungkapkan makna dalam teks monolog/esei tulis berbentuk report, narrative, dan analytical exposition secara akurat, lancar, dan berterima dalam konteks kehidupan sehari-hari dan mengakses ilmu pengetahuan" (Depdiknas, 2006). It means that the students of senior high school is expected to be able to express a written text in the form of report, narrative and analytical exposition accurately, fluently, and acceptably in the context of daily life. In fact, the expectation underlining in the curriculum description is still far from the ideal condition. Most of secondary school English teachers claim that meeting the standard of writing competence is a very hard work. The reason is based on difficulties of writing as explained above. In their practice, English teachers are required to make preparation before teaching in the classroom. So a teacher should construct the indicators and the goals of teaching related to the text types which are going to be taught, based on the competence standard outlining in the curriculum, then he/she has to write a lesson plan as his/her guide in teaching activities.

Since teaching students to write is frequently felt challenging by most of EFL teachers, the design of the instruction should be conducted as attractive as possible. Harmer, (1998) suggests that the teacher should apply a method, a strategy or a technique which can encourage the students to be more active in teaching and learning process of writing. There are many strategies and medium can be applied in teaching this skill. One of the strategies is teaching writing through story telling. Therefore, the present study applied a teaching strategy namely "what 
happen next?" strategy to improve the students' skill in writing a narrative text which was conducted at Madrasah Aliyah (MA) Muhammadiah Malang.

Before conducting the research, as a preliminary study, the researcher found that only 5 of 24 second year students of "Jurusan Bahasa" had met the minimum passing grade that was 65 . Next, an interview was conducted with the English teacher and some problems were identified as following: first, the students found it difficult to construct grammatical sentences. Most of the students were confused to write correct English sentences, they usually constructed sentences using the style of "Bahasa Indonesia". Second, they have so limited vocabularies that they depend on the dictionary very much. Through an interview the students told that they don't know the strategy to memorize English words. The third problem was most of the students get difficulties in developing their ideas. When the students were asked to write a paragraph, they could only write a few sentences. They had lack ideas to develop more sentences to produce a paragraph. For example, once the teacher asked them to write a paragraph based on the pictures, most of them wrote a story which was not related to the instructions and even to the theme of the pictures. Moreover, based on an interview with the students, they told that they got difficulty in memorizing vocabularies. It means they have very lack of vocabulary.

Based on the problems revealed above, the researcher and the English teacher decided to collaborate in solving such problems in writing a narrative text. The strategy applied in this study was actually in the form of story-retelling. But the way to tell the story is combined by inviting the students to activate their imagination that they get involved in the story. Teacher is required to be able to bring the students imagination that they are being experiencing the story. So, the teacher is supposed to tell the story as clearly as possible by using clear language which can be understood easily by the students. In telling a story teacher must be sure that the students are really imaging that they are the actor or the character in the story. This strategy is chosen because it can develop the students' imaginative thinking which helps them to develop their ideas in writing more sentences. In this way, the students become more creative in writing a narrative text since they are encouraged to experience the story through their imagination. In other words, stories can be used to develop students' imagination and inspiration. Through story, children delight in imagination and fantasy (Jalongo, 1992: 143). In addition, Tomlinson and Brown (2002: 4) reveal that through the experience of entering a different world from their own, children develop their imagination. It means that children have great imagination, and they can use their imagination when they listen to a story.

Telling the students a story is a proper way to motivate them in developing their thinking skill. Engaging in story retelling activities is a way to motivate even the most reluctant reader or writer (Miller and Pennycuff, 2008). Since they enjoy listening to the story, they will also enjoy expressing the story itself. This attitude can be used by the teacher to help them expressing the story in written form. This principle is supported by Wright (1995) who says that story plays an important role in motivating students. Through listening to the story told by the teacher, the students can expand their language abilities, help them learn the characteristics of the stories, and develop interpretation of the stories which is used in writing a narrative text. Briefly, it can be 
said that stories are motivating for the students. Wright (1995) and Ghosn (2002) reveal that stories offer an alternative as a motivating medium for foreign language acquisition. The students are usually interested in the characters, plot or another element of story, and they will be willing to listen to the story. When they are listening to stories, students are trained to concentrate and follow event-structured material (Jalango 1992).

Based on the problems revealed above and the explanation of how story-retelling could help students in writing narrative text, the researcher conducted a Classroom Action Research (CAR) using "What happen next?" story-retelling strategy. It was to solve the students' problems of second year students of Madrasah Aliyah Muhammadiyah Malang in writing narrative text. In this respect, the researcher formulate three research questions as follows: Questions:

1. Can and to what extend the strategy of "What happen next" improve the skill of the second year students of Madrasah Aliyah Muhammadiyah Malang in writing narrative text?

2. How is the situation of the classroom when the strategy is applied?

\section{Method}

Since the purpose of the research was to improve the students' skill on writing narrative texts by using a story-retelling strategy, classroom action research was the appropriate method to be conducted. This study involved 24 second year students of language department program. The procedure of this research was manipulated into four steps, namely planning, implementation, monitoring, and reflection. Each step was collaboratively done with the English teacher. The study was conducted in two cycles. Before applying the action pre-observation and analysis was done to observe and map the problem in the teaching and learning of writing. In this step, the researcher and the teacher discussed and formulated the indicators of students' problem in the learning of writing narrative text. In detail, table 1 shows the indicator of the problem, action and output.

Table. 1

\begin{tabular}{lll}
\hline \multicolumn{1}{c}{ Problems } & \multicolumn{1}{c}{ Action } & \multicolumn{1}{c}{ Output } \\
\hline $\begin{array}{l}\text { Writing skill in writing a narrative } \\
\text { text was low }\end{array}$ & $\begin{array}{l}\text { Implementing "what } \\
\text { happen next” a } \\
\text { storytelling strategy }\end{array}$ & $\begin{array}{l}\text { Quantitative: } \\
\text { (the writing skill was increasing } \\
\text { and it was measured by using } \\
\text { descriptive statistics) }\end{array}$ \\
\cline { 1 - 1 } $\begin{array}{l}\text { The teaching and learning } \\
\text { atmosphere in the classroom of } \\
\text { writing was not very good }\end{array}$ & & $\begin{array}{l}\text { Qualitative: } \\
\text { (The situation of the writing } \\
\text { class was getting better because } \\
\text { of the action) }\end{array}$ \\
\end{tabular}


The next procedure of the research was designing a lesson plan or instruction design based on the results of pre-observation and analysis. The English teacher acted as observers while the researcher acted as teacher. While executing the planning in classroom, the English teacher of the school observed the instruction process, which used "what happen next" to improve students' writing skill. The instructions of teaching writing through this strategy were conducted in the following steps which were adopted from Short, 1999:

a. Ask the students to place a sheet of paper in front of them on the desk.

b. Inform the students that they are going to be told a story. Tell them to sit back and make themselves comfortable, close their eyes and just listen.

c. Ask them to imagine that they are small children about 9 or 10 years old. They have been taken from their parents to an airport to be sent away from their country because there is a danger

d. Continue by telling them how they have been flying for about three hours, which seems like a long time to a child. Stop and ask students to open their eyes and write five or six sentences quickly about how they think they would feel in this situation.

e. When the students have finished, tell them to sit back, get comfortable again, and close their eyes.

f. Continue the story: they have been flying for some time and suddenly the plane seems to be doing strange things. It is out of control and falling towards the earth. The plane crashes, but they not hurt. Somehow they still alive and can move. They get out from the wreckage and look around.

g. The students to open their eyes again and quickly write what they are thinking and feeling.

$\mathrm{h}$. Let the students to continue writing a narrative text based on initial story told by the teacher.

Finally, the reflection was conducted to evaluate the process of teaching and learning applied by the teacher based on the last planning. Reflections also included to what had been learned, the barriers to the change, how to improve the change to next cycle. So, evaluation was done on the implementation of planning and the results of observation.

\section{Findings}

The research was conducted in two cycles. Each cycle applied two meetings of teaching and learning action and each meeting lasted for 90 minutes. The result of the first cycle became the consideration in deciding and planning the second cycle. The phases of activities of teaching writing by using storytelling were based on the lesson plan. After conducting the actions, some findings can be identified during and after the application of the strategy in each cycle. 
Cycle I was conducted in two meetings. The first meeting was for the implementation of "what happen next?" strategy and the second meeting was for refreshment of the first meeting and students activities of writing the narrative text based on the story that has been told.

At the first meeting, the teaching and learning processes were conducted through three stages of activities: pre-activities, main activities, and post activities. At the pre-activities, the teacher explained the objective of the teaching and learning. Then she asked the students about their understanding on narrative text as to activate the students' prior knowledge. Luckily, almost all the students seemed to understand the concept of narrative text. They know the purpose, the generic structure, and the other characteristics of the text. This could help the researcher to apply the strategy in teaching writing narrative texts. Then, the teacher asked the students about how they like listening to a story. They said that when they listen to a story they get easy to understand the idea of the story. One of them said that when he enjoyed a story, he could retell it in oral or written more easily.

In the main activities, the teacher firstly asked the students to put down their pen, close their eyes, sit in relax and ready to listen to the story. In this stage, the teacher must be able to seize the class to make sure that every students was concerning to the story. When the researcher was implementing the strategy, the English teacher acted as the observer. In this way, the observer noted her findings during the process. She noted the activities of the teacher and students based on the indicators which are listed on the observation guidelines. The result of the observation during the teaching process in applying the strategy revealed that all students show their good attitude toward the using of the strategy. They gave more attention to the teacher. They were encouraging to write, even though some of them still asked some questions about the vocabularies.

The students' attitude toward the implication of story-retelling strategy was revealed based on the result of the observation and the questionnaire answered by the students. One thing that made the students enjoy the activities was the effort of activating their imagination and fantasy in writing the story. As they were invited to imagine that the characters of the story were the students themselves, they felt more inspired to find the ideas. They enjoyed playing with their imagination. Through this activity, they could write a longer story, because they maximized their effort in picking up more and more vocabularies even though they still needed a help from the teacher. Moreover, the curiosity of the students about the story inspired them to get more ideas to be written because the teacher only told them a half of the story and the students were asked to continue the following story until the ending of the story. So, there was an improvement of students' motivation in writing, and the activities of writing in the classroom became more attractive. It was shown when they were asked to do the activities of the instruction, they were serious and enthusiastic. It means that the problems revealed by the English teacher as explained in the interview that the students had low motivation was able to be coped.

The implementation of the strategy in Cycle II was to revise the activities which seem as the shortage in Cycle I. It means that the students' activities in Cycle II were not different from the activities in Cycle I. The difference was on the treatment which was needed for the improvement 
in increasing the length of the story. So, in Cycle II, the teacher gave more explanation and exercises on constructing sentences and enrichment on vocabularies. To make sure that the activities became more attractive in Cycle II, the teacher used a short video to help the students getting more ideas and vocabularies.

Since there was an improvement of the classroom situation during the teaching and learning process through the strategy of "what happen next?" the achievement of the students in writing skill improved. It was found that the number of the students who met the minimum passing grade increased from only 5 out of 24 students (20.8\%) achieving the score above the minimum passing grade in the preliminary study to 18 students $(75 \%)$ in Cycle I. Then in Cycle II the numbers of the students who reached the minimum passing grade increased to 22 students $(91 \%)$. Besides, the improvement can also be seen at the average score achieved by the students. It increased from 58.5 in the preliminary study to 69.17 in Cycle I and 73.68 in Cycle II. So, the means of the students' score in Cycles I and II were above the standard of the minimum passing grade (the minimum passing grade set by the teacher was 65).

\section{Discussion}

The result of this research reveals that there was an improvement in writing a narrative text for the second year students of Madrasah Aliyah Muhammadiyah Malang. The improvements were in both students' achievement and the students' attitude toward the lesson of writing when the strategy of "what happen next" was applied. The improvement of students' achievement was shown by the improvement of the percentage of the score gained by the students after the action of the teaching and learning. In Cycle I the percentage of the students who were successful in meeting the minimum standard grade was $75 \%$ while in Cycle II the percentage improves to $91 \%$. Moreover, the score the students reach for every elements of writing increased in average from the result of preliminary research through Cycle I and Cycle II.

The mean of students' score on content increase from 17.4 in preliminary research, 18.76 in cycle one to 19.3 in cycle two. This improvement indicated that the implementation of the strategy could really help the students to solve their problem in writing narrative since the strategy was attractive for them especially to use their imagination to create more sentences for their composition. It was easy for them to write the problems which occurred in the story and right away got the idea of the solution of the problems. This is in accordance with Campbell (2009) who reveal that story-retelling is a powerful tool to get students writing because it provides opportunities to identify important details and dialogue understand and recall stories and story elements. Through story-retelling the students find it easy to retell the story they have listened for their writing product. Butcher (2006) stated that stories can change a student's perspective. There are often implicit morals to stories. They are less abstract and can be very powerful at looking at problems from other viewpoints. Even though it might be challenging, stories promote thinking 'outside of the box', which is an enormous factor in the learning process. 
Stories allow for development of critical thinking. In the same view, Patience (2012) in his action research on using storytelling as a strategy to improve the students' writing achievement found that students were especially excited that they had the option to express their own ideas, which contributed to the enthusiasm with which they responsibly did their writing exercise.

Meanwhile, the increase of the students' mastery on grammatical sentences was reflected at the average score reached by the students both in Cycle I and Cycle II. It increased from 14.5 in the preliminary study to 17.1 in Cycle I and 18.5 in Cycle II. The students' progress on writing the grammatical sentences was the result of the teachers' explanation during the process of teaching learning and exercises done by the students when they were asked to write sentences on the whiteboard. The students got more understanding on the concept of past tense, the order of noun phrases, and the correct arrangement of the sentences.

The improvement on vocabulary was the result of the students' enthusiasm on finding the words to be used in their composition. The students were active in asking the teacher the English words that they use for their composition. They were also encouraged to use their dictionary to find the words. The students' average score on vocabulary increase from 12.2 in preliminary study to 14.6 in Cycle I and 17 in Cycle II. Furthermore, the result of the organization of the story written by the students also increases in this study. Since the strategy of the storytelling was applied by telling the half of the story, the students were creative to find the ideas for continuing what happen in the next event of the story. As a comparison, some adult people who like to watch a serial drama were very curious to know the next story of the drama when it was paused. They would speculate about the next events of the story by guessing what happen next. This situation can be experienced by the students when they are told the beginning of the story. In this way the students find it easy to organize the structure of the text when they are writing. As result, the students' score on this aspect proved the students' improvement. The increase was from 10.9 in the preliminary study to 12.7 in Cycle I and 13.3 in Cycle II. The last aspect of writing is mechanic. The improvement of this aspect was as the result of students' feedback of the students work when they did an exercise in writing paragraph. Students were introduced the correct spelling of the words as well as the mechanics of the text. The result showed that the increase was from 3.5 in the preliminary research to 5.7 in Cycle I to 6.6 in Cycle II.

In the process of teaching and learning, the activities were dominated by the activities of the learners in investigating the vocabularies and thinking about how to construct grammatical sentences using the words that they listen when the story was being told. In this way, the learners were playing the role as the learner centered process. The teacher also played an important role in guiding the students' activities. Yuling (2004) explained that storytelling as a post-text activity is an example of learner-centered process that guides students to apply information and convey messages to others.

The improvement of the students' attitude toward writing was shown when the strategy of "what happened next? "was applied. The students were encouraged to find and to explore the ideas about the continue of the story. It let the students make their own choice about the solution of the complications created in the story, because the story was told by asking the students to 
think that the events through the story were experienced by themselves. This activity invited the students to feel that what was happening in the story was the experiences of themselves. Butcher (2006) stated that story enriches and compliments our own experience. Story teaches us about the opportunities, the consequences of action, the alternatives and the choices in life. In other words, the students were more creative in plotting the story, inventing the possible problems as well as the solution. Their imagination helps them exploring more and more ideas to be written.

\section{Conclusion}

It is revealed in the finding of this study that "what happen next" is a strategy which could help the second year students to solve their problems on writing narrative text. The students found it easier to finish their writing task since they could develop their ideas based on the story which was told by the teacher. The strategy of "what happen next" which was adapted from Short (1999) was implemented by activating the students imagination to think that what happened in the story was experienced by the students themselves. It made the student more motivated in writing because they were freer to express their feeling and mind. Through this process, the students were also more active to do exercises on constructing sentences, because at the middle of the activities on listening to the story, the teacher paused the story and the students were asked to write several sentences about what they felt or they thought when they imagined that they experienced the story being told by the teacher. In addition, the strategy of the "what happen next" was constructed by telling the students a half of the story and the students were assigned to continue the story based on their own imagination about "what happen next" in the story. As a result, the students enjoyed writing the story and they could write a longer text since they found it easy to organize the story. So, it can be concluded that teaching and learning process of writing narrative text by applying "what happen next" strategy could improve the students' skill on writing narrative text. The improvement was both in the students' writing ability and their attitude toward the teaching and learning process of writing in the classroom. Therefore, based on the result of the study, English teachers of senior high school are suggested to apply this strategy to improve the students' writing skill especially in writing narrative texts.

\section{References}

Alsamadani, H.A .2010. The Relationship between Saudi EFL Students' Writing Competence, L1 Writing Proficiency, and Self-regulation. College of Education, Um-Alqura University. European Journal of Social Sciences - Volume 16, Number 1

Butcher, Susan E. (2006) Narrative as a Teaching Strategy. The Journal of Correctional Education 57(3) 
Campbell, Terry A (2009) Storytelling and Story Writing "Using a Different Kind of Pencil" Nipissing University and Michelle Hlusek, Nipissing-Parry Sound Catholic District School Board

Cahyono, B.Y. \& Widiati.U.. 2011. The Teaching of English as a Foreign Language in Indonesia. Malang. State University of Malang.

Depdiknas, 2006. Kurrikulum Tingkat Satuan Pendidikan (School Based Curriculum). Jakarta: Depdiknas.

Ghosn, I.K. 2000. Four Good Reasons to Use Literature in Primary School ELT. ELT Journal, 56(2): 172-179

Harmer, J. 1998. How to Teach English: An Introduction to the Practice of English Language Teaching. London: Addison Wesley Longman Limited.

Jalango, M.R. 1992. Early Childhood Language Arts. Massacussets: Allyn and Bacon

Karlisson, Patience A. (2012) Storytelling as a Teaching Strategy in the English Language Classroom in Iceland. M.Ed. thesis in the teaching and learning of foreign languages, Faculty of Teacher Education School of Education, University of Iceland

Miller, Sara and Pennycuff, Lisa. 2008. The Power of Story: Using Storytelling to Improve Literacy Learning. Journal of Cross-Disciplinary Perspectives in Education Vol. 1, No. 1 (May 2008) $36-43$

Richard, J. C, and Renandya, W. A.2002. Methodology in Language Teaching: An Anthology of Current Practice. United Kingdom. Cambridge University Press.

Short, D. J.1999. New Ways in Teaching English at the Secondary Level. USA, Bloomington, TESOL.Inc.

Tomlinson, C.M., and Brown, C.L. 2002. Essential of Children's Literature. Boston: Allyn and Bacon

Wright, A. 1995. Storytelling with Children. Oxport: Oxport University Press. 